Journal of Social Sciences (COES\&RJ-JSS)

ISSN (E): 2305-9249 ISSN (P): 2305-9494

Publisher: Centre of Excellence for Scientific \& Research Journalism, COES\&RJ LLC

Online Publication Date: $1^{\text {st }}$ April 2020

Online Issue: Volume 9, Number 2, April 2020

https://doi.org/10.25255/jss.2020.9.2.590.602

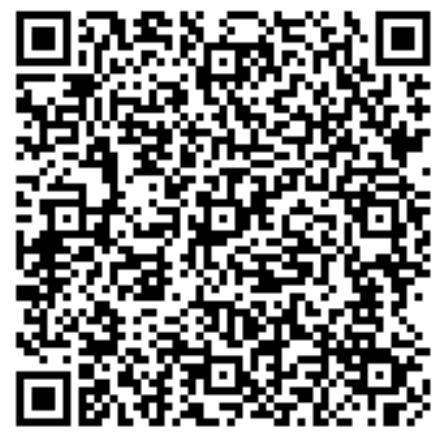

\title{
The ability of cash flows to predict the earning
} Omar Mohammad Al-Hawatmeh

https://orcid.org/0000-0002-4396-0584

\section{Abstract:}

This study aims to test is ability of cash flows to predict the earning, his research is expected to give contribution in providing evidence on whether

(1) operating cash flow is useful to predicting earning.

(2) Investing cash flow is useful to predicting earning.

(3) Financing cash flow is useful to predicting earning.

In the present research, Statistical population consists of firms listed on London Stock Exchange Group (LSEG) during 2015-2018. Earning (dependent variable) was measured by net income, operating income and independent variable, namely cash flows through operating, investing and financing operations. The results generally indicates the models' ability to interpret hypothesis and confirm the ability of cash flows to predict earnings.

\section{Keywords:}

Cash Flow, Earning, Prediction, Component of Predictive Earning, London Stock Exchange Group (LSEG).

\section{Citation:}

Al-Hawatmeh, Omar Mohammad (2020); The ability of cash flows to predict the earning; Journal of Social Sciences (COES\&RJ-JSS), Vol.9, No.2, pp:590-602; https://doi.org/10.25255/jss.2020.9.2.590.602. 


\section{Introduction}

The purpose of this paper is to examine the test of ability of cash flows to predict the earning, and Prepare ability of the company to generate cash flows is an important element in the decision making process of its various stakeholders. Through prediction of cash flow financial statements users are able to assess firm's liquidity, financial flexibility and risks (Barth, Beaver, \& Landsman, 2001; Bhatia \& Dhamija, 2015).

The prediction of Earnings (ERN) and CF catches attention in the field of accounting and finance provided that the firms have capability to generate Cash Flows (CF). Several external parties to the firm are concerned with the prospects of firms' CF according to Financial Accounting Standards Board (FASB).

From the 1990s, many researchers addressed interest in cash flows information. The International Accounting Standards Board (IASB) has adopted a perspective of decision usefulness in the formulation of its accounting principles and has given paramount importance to the accounting accruals in paragraph 24 of its conceptual framework in a way that "The majority of disclosures in the financial statements related to resources, commitments and their variations result from the application of accounting accruals, and also information related to cash flow"(Jemâa, Toukabri, Jilani,2014).

This paper examines this issue ability of cash flows to predict the earning; the rest of the study is organized as follows. The researcher starts with reviewing related previous literature on the predictive ability of operating cash flows and earnings. Then the study methodology is introduced including the study sample and period, the variables under examination, and models of the study. The final part of the study reports the empirical results and conclusions of the study.

Cash Flow Statements Earning is one of the basic measures number of important figures for the purposes of financial analysis is used to measure performance. It is important that it measure the normal activity of the establishment before part of it is distributed and another reservation according to the establishment laws before it is affected by the tax imposed on it. The company is able to predict the Earning and cash flows and to determine the extent to which it is held as part of the profits to fund the self-financed projects. We do not forget the impact of this figure on the market's financial bubble, as the shareholder is seen as an important indicator of decision making of Investment in the company's shares.

\section{Literature Review and Hypothesis Development}

This chapter demonstrates research work that had been previously performed in other countries in understanding the ability of cash flows to predict the earning. 


\section{The ability of cash flows to predict the earning}

\section{Meaning of cash flow Cash flow}

Information considered as the part of accounting information published and presented in the cash flow statement of a particular company (Farshadfar, Chew $\mathrm{Ng}$ and Brimble, 2008) and also Zwaig \& Pickett (2001) considered cash flow as significant financial indicator of financial problem where any decline in the amount of company cash flow will provide early signal warning of bankruptcy to the users like creditors and others.

The use of this information assists different users of accounting information including investors and others in serving their different purposes. Example investors or security analysts need such information for the purpose of valuing their investment in the capital markets (Chotkunakitti, 2005), managers need such information for the purpose of identifying financial problem that will face the company in the near future (Kelly \& O'Connor 1997) while management need such information for the purpose of knowing the available amount of cash in the company (Schaeffer 2002).

Researches on the information contained within earnings were first done by Ball and Brown (1968). From the study, they found significant relationships between 'unexpected earnings' and 'abnormal return'. This study was then followed by Beaver (1968), Lipe (1986), and Bernard and Stober (1989). Fairfield et al. (1996) researched on whether a more detailed earnings report was better than the relatively less detailed earnings classification in determining the ROE of the following year. In Indonesia, studies on the benefits of using earnings data in predicting future earnings has been done by several researchers, among others are: Parawiyati (1996), Sunariyah (1996), Isgiyarta (1997), Parawiyati and Baridwan (1998), Werdiningsih (2000), Madjid (2002) and Kholidiyah (2002). Supriyadi (1999) found that using the data on a company's cash flow provided better information to assess future cash flow of the company. The other thing he discovered was that using cash flow in his study to predict future cash flow was not as good as the model using the combination of both earnings and cash flow. Cheng, et al. (1996) as quoted by Kusuma (2003) examined the additional benefit of the information contained within earnings and cash flow using linear and nonlinear models. This research was able to provide empirical evidence that the information contained within earnings and cash flow had additional value. Parawiyati, and 2 Baridwan (1998) found that both earnings and cash flow are significant factors to predict future earnings and cash flow for the one year ahead. Next, Utami (1999) confirmed that cash flow can be used to predict coming cash flow, although in the long run, the effectiveness of using data on cash flow for forecasting is about the same as using data on earnings. 
Foster (1977a) evaluated models of expected earnings by using those models to predict earnings, and then by comparing the dynamics of the stock prices to the degree of error of the models used for making the predictions.

Patell (1976a) tested the information contained within the earnings forecasts made by the management. Several other studies such as Copeland and Marioni (1972), Hagerman and Ruland (1977) and McDonald, Lorek, and Patz (1976) concluded that the forecasts made by the management was accurate, as proven when the forecasts came true (Kholidiah, 2002).

This chapter demonstrates research work that had been previously performed in other countries in understanding the ability of cash flows to predict the earning.

\section{Cash Flow Prediction}

Cash flow in accounting, the balance sheet is a snapshot on a company's finances at a fixed time; that reflect the changes in company finance over a long period. Cash flow prediction to be the most important and useful factor required in the various economic decision like investment decision, lending decision and other financial decision by accounting information users (Mulenga, Bhatia ,2017) (Chotkunakitti, 2005), because it helps them in assessing firm's liquidity, financial flexibility and risks (Barth et al.,.2001).Furthermore, FASB (1978) observed the task of predicting future cash flow as the primary objective of financial reporting (Mulenga, Bhatia, 2017).

The concept of cash flow prediction is not only interesting and important for the company's business, investors, creditors, financial analysts among others but also for academic researchers (Mulenga, Bhatia, 2017). Through prediction of cash flow financial statements users are able to assess firm's liquidity, financial flexibility and risks (Barth, Beaver, \& Landsman, 2001; Bhatia \& Dhamija, 2015; Mulenga, Bhatia, 2017)

The importance of Future Cash Flow Prediction. The availability of an optimum level of Cash to a firm is "king". This is because a firm can be operating at a profit but suddenly go insolvency if it runs out of cash in the course of business and cannot obtain cash (Keown, Martin, Petty \& Scott, 2005; Born et al., 2014). Both financial and non-financial organizations are constantly faced with the risk of variations in their flow of cash. The receipts coming into an organization must exceed their cash payments in the long run so as to ensure the solvency of that organization. For firms, the timing of cash receipts and when it can be invested as well as when cash can be paid back to shareholders as a dividend is of great concern (Keown et al., 2005). 
Financial information users are, therefore, primarily concerned with the ability of firms to generate Cash Flows that are favorable to future financial obligations. Financial decisions of firms are, however, linked to the timing, volume and uncertainties in future Cash Flows (FASB, 1978). According to Elahi (2013), the current high level of volatilities in the world of business will grow worse in the years to come. It, therefore, becomes imperative for analysts and business players especially younger firms which most especially face uncertainties in their growth prospects to obtain prior knowledge on the trend of their future Cash Flows. The uncertainties in the growth of young firms are exhibited through the passage of time with the realisation of future Cash Flow and make available evidence about their financial health (Alti, 2003). Accounting information reported by firms is increasingly gaining usefulness to their users in forecasting future Cash Flows as a foundation for making sound financial decisions (Obinata, 2002). In the United States, the call for Cash Flow prediction by investors in the capital market has been on the rise especially for firms with unstable earnings, large accruals, varied accounting practices choices and high capital intensiveness (DeFond \& Hung, 2003). Financial analysts, as part of their main activities, make use of financial information in order to forecast the performance of a firm as related to earnings, Cash Flows beside share prices (Ramnath, Rock, \& Shane, 2008).

Previous studies have, therefore, validated the use of accounting information as a crucial source of data for executing the decision-making process by analysts (Chang, Khana, \& Palepu, 2000; Alti, 2003). Forecasting future Cash Flows with data obtained from reported accounting information, therefore, aids in the appraisal of investments from the long-term and short-term perspectives, valuation of securities, valuing credit and facilitating the process of decision making in an organization with the ultimate goal of ensuring the profitability and solvency of a firm.

\section{Cash Flows Component}

Cash flow statement has three components:

1. Cash flow from operating activities (cash flow related to sales, cost of goods sold, and other operating expenses)

2. Cash flow from financing activities (cash flow related to interest, taxes, and other expenses)

3. Cash flow from investing activities (cash flow related to change in company assets: the sale of financial or real assets, repayments for long-term loans, investments in equipment or assets acquisition. 


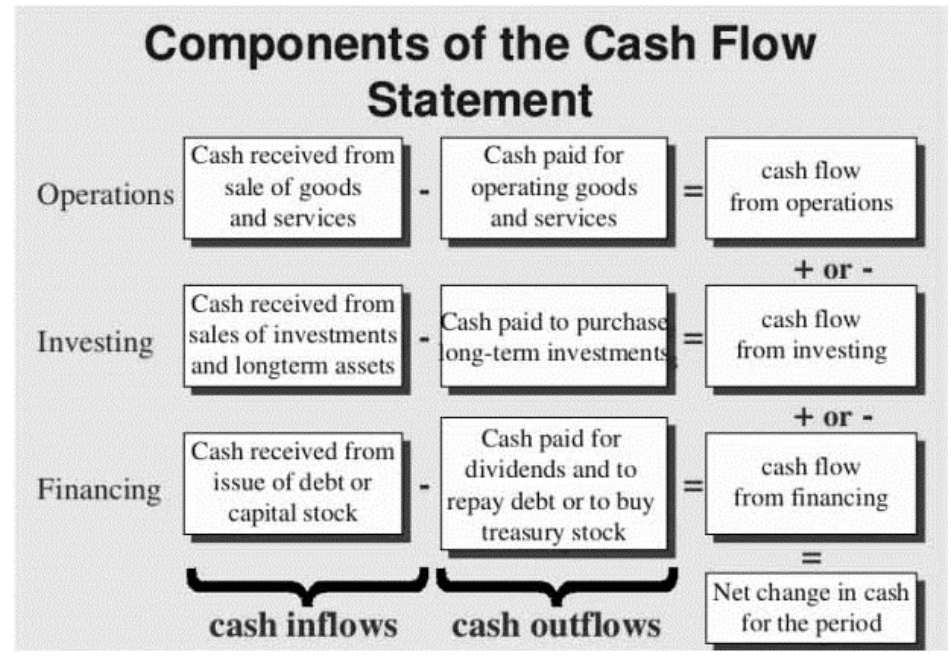

So that we should take in account two points when we analyze cash flow:

a. the cash items at the beginning

b. and the cash items at the end

Broome (2004) describe operating cash flows as those cash flows that are related to the corporation's operating activities (i.e. those activities reflected in the corporation's income statement). The cash flows from operating activities are derived from a section in the statement of cash flows in IFRS statement IAS 7.

IFRS further elaborates that cash flows from operating activities are primarily derived from the principal revenue-producing activities of the entity and generally result from the activities that generate entity's profit and/or losses (IFRS-IAS 7, para. 14).

\section{Cash Flow Statement Format}

1. Operating Activities: Net Income + Depreciation and Amortization

+/- One Time Adjustments (i.e. investment gains or losses not related to operations, deferred taxes, stock compensation)

+/- Changes in Working Capital = Cash Flow from Operations

2. Investing Activities:

+/- Net Capital Expenditures +/- Net Investments = Cash Flow from Investing Activities

3. Financing Activities - Dividends

+/- Sale or purchase of company stock

+/- Net borrowings $=$ Cash Flow from Financing Activities

* Summary of Cash Flow Activities:

+/- Cash Flow from Operating Activities +/- Cash Flow from Investing Activities 
+/- Cash Flow from Financing Activities = Net Change in Cash + Beginning Cash Balance $=$ Ending Cash Balance

\section{Cash flow measurement}

In order to identify cash inflows and cash outflows there are two methods: direct method and indirect method The difference between the two methods is restricted to the measurement of cash flows related to operating activities, cash flows associated with investment and financing activities do not vary according to the preparation methods, if any two methods used when preparing cash flows from investment and financing activities, the result is the same. International accounting standards explain these two approaches: Under direct method cash receipts (such as cash receipts from sale of goods or rendering services) and cash payments (such as cash payments to suppliers for the purchase of goods and for employees), both are disclosed separately, Orpurt and Zang (2009) demonstrated that direct method provides information which may be useful in estimating future cash flows and future earnings. According to Jones et al. (1995), Kojima (2012), Widjaja (1998), direct method is better for understanding cash flow data (Hardan, Qabajeh, Alshanti, 2016). Jones et al. (1995) found that direct method facilitates cash flow analysis, and is a better indicator of company solvency (Hardan, Qabajeh, Alshanti, 2016). But the indirect method depend on the net income elements to get net cash flows that affect by the change in variable factor such as payables, accounts receivables, and inventories,. So that the indirect method gives less information comparing with direct method. .

\section{Earning}

Earnings is a measure of performance during a period that concerned primarily with the extent to which asset inflows associated with cash-to-cash cycles substantially completed (or completed) during the period exceed (or are less than) asset inflows associated, directly or indirectly, with the same cycles. Both an entity's ongoing major or central activities and its incidental or peripheral transactions involve a number of overlapping cash-to-cash cycles of different lengths (Dechow, s.p.kothari, 1997). At any time, a significant proportion of those cycles is normally incomplete, and prospects for their successful completion and amounts of related revenues, expenses, gains, and losses vary in degree of uncertainty. Estimating those uncertain results of incomplete cycles is costly and involves risks, but the benefits of timely financial reporting based on sales or other more relevant events, rather than on cash receipts or other less relevant events, outweigh those costs and risks (Dechow, 1997).

Earnings also used as the driver of the value of the company (Beisland, 2011).In accounting, earnings occupy a key position and considered as an important measure which show the summary of accounting that assisting in measuring 
performance of the firm in debt contracts and management (Maureen F. McNichols, Stephen R. Stubben, 2014) (Dechow, Kothari and Watts, 1997) and valuation of company"s share (Push Bhatt and Sumangala, K., and Dechow, Kothari and Watts, 1997). Regarding the uses of earnings in predicting future cash flows, the study of Farshadfar, Chew Ng and Brimble (2008) and Beisland (2011) used earnings after tax but before extraordinary items, and other researchers like Jemaa el al (2015) used net income and operating income as the proxy of earnings in their study. Operating earnings also use as the proxy of earnings in the study of Ahmadi, A and Ahmadi, V. (2012) and Bagheri, Pouraghajan and Emmgholipour (2012) (Mwila Joseph Mulenga, 2015).

From the review of literature, most of the previous work focused on measuring ability of earnings, cash flow from operations and accruals in forecasting future cash flow were coming from the developed countries.

\section{Hypothesis}

H1: Operating cash flows (OCF) have statistically significant effect on predict the earning (ER).

H2: Investing cash flows (ICF) have statistically significant effect on predict the earning (ER).

H3: Financing cash flows (FCF) have statistically significant effect on predict the earning (ER).

\section{Methodology \\ Sample}

In the present research, Statistical population consists of firms listed on London Stock Exchange Group (LSEG) during 2015-2018.The Group operates a broad range of international equity, ETF, bond and derivatives markets, including London Stock Exchange; Borsa Italiana; MTS (a European fixed income market); and Turquoise (a panEuropean equities MTF), In addition to majority ownership of LCH, a multi-asset global CCP operator, LSEG owns CC\&G, the Italian clearinghouse and Monte Titoli, a leading European custody and settlement business.

LSEG Technology develops and operates high performance technology solutions, including trading, market surveillance and post trade systems for over 40 organization's and exchanges, including the Group's own markets.

\section{Definition of variables}

The research variables are summarized in Table 1. 


\begin{tabular}{l|l} 
VARIABLES & DEFINITION \\
\hline ERN & Earning \\
NI & Net income \\
OI & Operating income \\
CF & Cash flow \\
OCF & Operating cash flow \\
ICF & Investing cash flow \\
FCF & Financing cash flow \\
Total assets divide all variables. &
\end{tabular}

Table 1:

Earning: Regarding the earnings (dependent variable), two variables are used: net income and operating income. The choice to use two indicators to test the impact of the eability of cash flows to predict the earning finds its explanation in the interpretations presented by (Dechow, 1994; and De Angelo, De Angelo and Skinner, 1992; Fedhila, 2003).

Model

Earnings (Ear) represent the sum of elements cash flow and cash flow (CF) and an accrual (AcC) component. Earning is measured as,

$\mathrm{ERN}=\mathrm{ACC}-\mathrm{CF}(1)$

Where the variable earnings, ERN, is net income. Some studies measure earnings differently. For example, Freeman, Ohlson and Penman (1982), use net income, while Dechow (1994); and Moehrle, Reynolds-Moehrle and Wallace (2003) use net income excluding extraordinary items and discontinued operations.

$E R N=\alpha+\beta 1$ OCF $+\beta 2$ ICF $+\beta 3$ FCF $+\varepsilon(2)$

$\mathrm{ERN}=\alpha+\beta 1 \mathrm{OCF}+\beta 2 \mathrm{ICF}+\beta 3 \mathrm{FCF}+\beta 4 \mathrm{CH}+\varepsilon$ (3)

$\mathrm{ERN}=\alpha+\beta 1 \mathrm{NI}+\beta 2 \mathrm{OI}+\varepsilon(4)$

\section{Result}

The results generally indicates the models' ability to interpret hypothesis and confirm the ability of cash flows to predict earnings.

Table 2 shows a correlation matrix for the search variables. The links on the main diameter are the correlations between each variable and itself, which is why they are all 1, the correlation is statistically significant at "Sig. (Binary tail)" $<0.05$. The numbers below the diameter express the relationship of the variables with the dependent variable and found that all of the negative relationship CF, OCF, ICF, and FCF a positive relationship. 
Table 2

\begin{tabular}{|l|l|l|l|l|l|l|}
\hline \multicolumn{2}{|l|}{ Correlations } & ERN & CF & OCF & ICF & FCF \\
\hline \multirow{4}{*}{ Pearson Correlation } & ERN & 1 & -0.358 & -0.065 & -0.425 & 0.292 \\
\cline { 2 - 7 } & CF & - & 1 & 0.922 & 0.299 & -0.302 \\
& & 0.358 & & & & \\
\cline { 2 - 7 } & OCF & - & 0.922 & 1 & -0.057 & 0.024 \\
& & 0.065 & & & & \\
\cline { 2 - 7 } & ICF & - & 0.299 & -0.057 & 1 & -0.989 \\
& & 0.425 & & & & \\
\cline { 2 - 7 } & FCF & 0.292 & -0.302 & 0.024 & -0.989 & 1 \\
\hline
\end{tabular}

The descriptive statistics presented below show that the average of cash flows are positive. The most number of points observed on the ERN, the dependent variable. The minimum cash flow (CF) score was significantly lower than the minimum scores for other variables. Note that the standard deviation of both investment and financing cash flows has increased.

Table 3

\begin{tabular}{|c|c|c|c|c|}
\hline \multicolumn{5}{|c|}{ Descriptive Statistics } \\
\hline & Minimum & Maximum & Mean & Std. Deviation \\
\hline ERN & 0.003451402 & 0.0039838 & 0.00369668 & 0.000260926 \\
\hline CF & -0.00037801 & 0.00029111 & 5.1922E-05 & 0.000297089 \\
\hline NI & 0.000569499 & 0.00159377 & 0.00087305 & 0.000482741 \\
\hline OI & 0.000216805 & $\mid 0.00094565$ & 0.00074705 & 0.000353981 \\
\hline FCF & -0.00170355 & -0.00095035 & -0.0012298 & 0.000331876 \\
\hline ICF & 0.000185645 & 0.0011065 & 0.00047899 & 0.000433491 \\
\hline OCF & 0.000391292 & \begin{tabular}{|l|l|}
0.0010748 \\
\end{tabular} & 0.00080272 & 0.000290691 \\
\hline
\end{tabular}

\section{Conclusion and Recommendation}

This study's main objective is to verify the ability of cash flows to predict the earning, we rely on previous studies models, we offer in this study clarification on the role of ability of cash flows to predict the earning in the London Stock Exchange Group (LSEG). This study, we analyze a Statistical population consists of firms listed on London Stock Exchange Group (LSEG) during 2015-2018.

The results showed a strong correlation between variables and that cash flows have the ability to predict profits, that both operational and investment flows have strong predictability of profit, while financing flows are second in their ability to predict profit.

These results are important to stakeholders by enabling them to assess the company's liquidity, resilience and risk and thus their ability to know the earning. 
This study is limitless. In fact, the sample is relatively limited to generalize the results.

Similarly, predictive studies of accounting information on a sample of heterogeneous firms can be a source of bias in existing findings, and the fact that the predictive power of the disclosure information elements may depend on economic conditions and firm's characteristics.

Previous studies use cash flows as a dependent variable to determine the effect of earning or the ability earning to predict flows. Therefore, the recommendations come for further research in this area.

\section{References}

Ahmadi, A., \& Ahmadi V. (2012), Evaluating the ability of operating cash flow predictive indexes. Interdisciplinary Journal of contemporary Research in Business, 4(7).

Alti, A. (2003). How Sensitive Is Investment to Cash-flow When Financing Is Frictionless? The Journal of Finance, 58(2), 707-722.

Ball, Ray, and Philip Brown, 1968. An Empirical Evaluation of Accounting Income Numbers. Journal of Accounting Research: 159-178.

Baridwan, Zaki, 1999. Intermediate Accounting, BPFE, Yogyakarta.

Barth, M. E., Cram, D. P., \& Nelson, K. K. (2001). Accruals and the prediction of future cash flows. The Accounting Review, 76(1), 27-58.

Beaver, William H., 1970. The Time Series Behavior of Earnings. Supplement to Journal of Accounting Research: 62-69

Born, P., Lin, H. J., \& Wen, M. M. (2014). Cash-flow Risk Management in the Insurance Industry: Adynamic Factor Approach.

Chang, J., Khana, T., \& Palepu, K. (2000). Analyst activity around the world. Working Paper.

Chotkunakitti, P. (2005). Cash flows and accrual accounting in predicting future cash flow of Thai listed companies. PhD thesis, Southern Cross University. 
DeFond, M., \& Hung, M. (2003). An empirical analysis of analysts Cash Flow Forecasts. Journal of Accounting and Economics, 35(1), 73-100.

Fairfield, et al., 1996. Accounting Classification and The Predictive Content of Earnings, The Accounting Review, Vol.71, No.3 (July): 337-355.

Farshadfar, S., Ng., C, \& Brimble, M. (2008), The relative ability of earning and cash flow data in forecasting future cash flows, Pacific Accounting Review, 20(3): 251-268.

FASB. (1978a). Financial Accounting in Non-business Organization: An Exploratory Study of Conceptual Issue. Norwalk: Financial Accounting Standards Board.

Foster, George, 1986. Financial Statement Analysis, Second Edition, Prentice-Hall International, 1977a.

Isgiyarta, Jaka, 1997. "Klasifikasi Akuntansi dan Kemampuan Prediksi Laba," Tesis S2, Universitas Gadjah Mada

Jones, S., \& Widjaja, L. (1998). The decision relevance of cash-flow information: A note. Abacus, 34(2), 204-219.

Jemaa, O.B., Toukabri, M. \& Jilani, F. (2015). The examination of the ability of earnings and cash flow in predicting future flows: application to the Tunisian context. Accounting and Finance Research.

Jones, S., Romano, C., \& Smyrnios, K. (1995). An evaluation of the decision usefulness of cash flow statements by Australian reporting entities. Accounting and Business Research, 25(98), 115-129.

Kojima, K. (2012). Decision usefulness of cash flow information format-An experimental study. International Review of Business, 12(3), 23-44.

Kelly, J. \& O'Connor, J. (1997).Is profit more important than cash flow?', Management Accounting, 75(6), 28-9.

Keown, A. J., Martin, J. D., Petty, J. W., \& Scott, D. F. (2005). Financial Management: Principles and Application (10th ed.). Upper Saddle River: Pearson Education.

Lipe R.C., 1986. The Information Contained in The Components of Earnings, Journal of Accounti“Kemampuan Laba dan Arus Kas dalam Memprediksi Laba 


\section{The ability of cash flows to predict the earning}

dan Arus Kas Perusahaan Go Publik di Indonesia", Jurnal Riset Akuntansi Indonesia, Januari: 1-11.

Obinata, T. (2002). Concept and relevance of income. Tokyo: Working Paper, University of Tokyo. - Orpurt, S., \& Zang, Y. (2009). Do direct cash flow disclosures help predict future operating cash flows and earnings? The Accounting Review, 84(3), 893-935.

Patricia M. DechowS. P. Kothari and Ross Watts, 1997. The relation between earnings and cash flows, Journal of Accounting and Economics, 1998, vol. 25, issue $2,133-168$.

Ramnath, S., Rock, S., \& Shane, P. (2008). The Financial Analyst forecasting literature: a taxonomy with suggestions for further research. International Journal of Forecasting, 24(1), 34- 75.

Schaeffer, H.A. (2002).Cash flow: the lifeblood of a business', Controllers Update, no. - 200(1), 3.

Zwaig, M.C. \& Pickett, M.M. (2001.) Early warning signs of a bankruptcy. Business Credit, 103, (1)-65.

Mulenga, Bhatia (2017), The Review of Literature on the Role of Earnings, Cash Flows and Accruals in Predicting of Future Cash Flows, Vol. 6, No. 2; 2017.

Hardan, Qabajeh, Alshanti (2016), the Preference of Direct or Indirect Methods in Preparing the Statement of Cash Flows in Decision Making: An Academic Perspective, Vol. 8, No. 2; 2016.

Trejo-Pech, Carlos O.; Noguera, Magdy; Samaniego-Alcántar, Ángel;Weldon, Richard N.(2012), The relationship between accruals, earnings, and cash flows: evidence from latin America.

Dechow, s.p.kothari (1997), the relation between earnings and cash flows.

Maureen F. McNichols • Stephen R. Stubben(2014), The effect of target-firm accounting quality on valuation in acquisitions, DOI 10.1007/s11142-014-9283-x.

Jemâa, Toukabri, Jilani(2014), The Examination of the Ability of Earnings and Cash Flow in Predicting Future Cash Flows: Application to the Tunisian Context, Vol. 4, No. 1; 2015. 